\title{
Rhodanobacter panaciterrae sp. nov., a bacterium with ginsenoside-converting activity isolated from soil of a ginseng field
}

\author{
Liang Wang, ${ }^{1} \dagger$ Dong-Shan An, ${ }^{2}+$ Song-Gun Kim, ${ }^{2}$ Feng-Xie Jin, ${ }^{3}$ \\ Sung-Taik Lee ${ }^{1}$ and Wan-Taek $\mathrm{Im}^{1}$
}

Correspondence
Wan-Taek Im
wandra@kaist.ac.kr

The genus Rhodanobacter, in the family Xanthomonadaceae, was originally described by Nalin et al. (1999) on the basis of a lindane-degrading bacterium isolated from soil of a woodtreatment site. Subsequently, several novel species have been classified as members of the genus Rhodanobacter, which at the time of writing comprised Rhodanobacter lindaniclasticus (Mergaert et al., 2002) and seven other species with validly published names: Rhodanobacter fulvus (Im et al., 2004), $R$. spathiphylli (De Clercq et al., 2006), R. thiooxydans (Lee et al., 2007), R. ginsengisoli and R. terrae (Weon et al., 2007), R. ginsenosidimutans (An et al., 2009) and R. soli (Bui et al., 2010).

†These authors contributed equally to this work.

Abbreviations: $\quad \mathrm{Rb}_{1}, \quad 3-\mathrm{O}$-[ $\beta$-D-glucopyranosyl-(1-2)- $\beta$-D-glucopyranosyl]20-O-[ $\beta$-D-glucopyranosyl-(1-6)- $\beta$-D-glucopyranosyl]-20(S)-protopanaxadiol; $\mathrm{Rd}, \quad 3-O-[\beta$-D-glucopyranosyl-(1-2)- $\beta$-D-glucopyranosyl]-20-O- $\beta$-Dglucopyranosyl-20(S)-protopanaxadiol.

The GenBank/EMBL/DDBJ accession number for the 16S rRNA gene sequence of strain LnR5-47 ${ }^{\top}$ is EU332829.
During a study on the cultivable aerobic bacterial community in the soil of a ginseng field in Liaoning province, China, many novel bacterial strains were isolated. One of them, designated LnR5-47 ${ }^{\mathrm{T}}$, which could convert ginsenoside $\mathrm{Rb}_{1}$ $\{3-O$-[ $\beta$-D-glucopyranosyl-(1-2)- $\beta$-D-glucopyranosyl]-20$O$-[ $\beta$-D-glucopyranosyl-(1-6)- $\beta$-D-glucopyranosyl $]-20(S)$ protopanaxadiol $\}$ to $\mathrm{Rd}\{3-O-[\beta$-D-glucopyranosyl-(1-2)$\beta$-D-glucopyranosyl]-20-O- $\beta$-D-glucopyranosyl-20( $S)$-protopanaxadiol\}, appeared to be a member of the genus Rhodanobacter.

Strain LnR5 $-47^{\mathrm{T}}$ was isolated using modified R2A agar, as described by Liu et al. (2006). Plates were incubated at room temperature for 1 month and single colonies were purified by subcultivation on full- or half-strength modified R2A agar or R2A agar (Difco). Strain LnR5-47 ${ }^{\mathrm{T}}$ was cultured routinely on R2A agar at $25{ }^{\circ} \mathrm{C}$ and maintained as a glycerol suspension $(20 \%$, w/v $)$ at $-70{ }^{\circ} \mathrm{C}$.

The Gram-reaction was performed by the non-staining method, as described by Buck (1982). Morphology of cells 
grown for 3 days at $30{ }^{\circ} \mathrm{C}$ on $\mathrm{R} 2 \mathrm{~A}$ agar was observed under a Nikon light microscope at magnification $\times 1000$. Motility was determined using the hanging-drop technique (Skerman, 1967). Catalase activity was determined by bubble production in $3 \%(\mathrm{v} / \mathrm{v}) \mathrm{H}_{2} \mathrm{O}_{2}$ and oxidase activity was determined using $1 \%(\mathrm{w} / \mathrm{v})$ tetramethyl $p$-phenylenediamine. Carbon-source utilization and enzyme activities were tested using the API 20NE, API ID 32GN and API ZYM systems (bioMérieux) at $30{ }^{\circ} \mathrm{C}$. Tests for the degradation of DNA (DNase agar; Scharlau; DNase activity detected by flooding plates with $1 \mathrm{M} \mathrm{HCl}$ ), casein, chitin, starch (Atlas, 1993), xylan and cellulose (Ten et al., 2004) were evaluated after 5 days. Anaerobic growth was performed in serum bottles containing R2A broth and sodium thioglycolate $\left(1 \mathrm{~g} \mathrm{l}^{-1}\right)$ with the upper air layer replaced with nitrogen gas. Conversion of ginsenoside $\mathrm{Rb}_{1}$ was determined using TLC analysis as described by Kim et al. (2005). Growth at $4,15,20,25,30,37$ and $42{ }^{\circ} \mathrm{C}$ and $\mathrm{pH} 5.0-10.0$ (at intervals of $0.5 \mathrm{pH}$ units) was assessed after 10 days in $\mathrm{R} 2 \mathrm{~A}$ broth. For the $\mathrm{pH}$ experiments, three buffers were used (final concentration, $50 \mathrm{mM}$ ): acetate buffer ( $\mathrm{pH}$ 5.0-5.5), phosphate buffer ( $\mathrm{pH}$ 6.0-8.0) and Tris buffer (pH 8.5-10.0). Growth with $1-10 \%(\mathrm{w} / \mathrm{v}) \mathrm{NaCl}$ was determined on R2A agar after 5 days at $30{ }^{\circ} \mathrm{C}$. Growth on nutrient agar, trypticase soy agar (TSA), MRS agar and LB agar (all Difco) was also evaluated at $30{ }^{\circ} \mathrm{C}$.

An almost-complete 16S rRNA gene sequence for strain LnR5 $-47^{\mathrm{T}}$ was determined. Genomic DNA was extracted using a commercial kit (Solgent). The 16S rRNA gene was amplified using the universal bacterial primer set comprising $9 \mathrm{~F}$ and $1512 \mathrm{R}$ and the purified PCR products were sequenced by Solgent (Ten et al., 2008). The 16S rRNA gene sequence was compiled using SeqMan software (DNASTAR). 16S rRNA gene sequences of related taxa were obtained from GenBank using the EzTaxon server (Chun et al., 2007). Multiple alignments were performed using CLUSTAL x (Thompson et al., 1997). Gaps were edited in the program BioEdit (Hall, 1999). Evolutionary distances were calculated using the Kimura two-parameter model (Kimura, 1983). Phylogenetic trees were constructed using the neighbour-joining (Saitou \& Nei, 1987) and maximum-parsimony (Fitch, 1971) methods in MEGA4 (Kumar et al., 2008), with bootstrap values based on 1000 replications (Felsenstein, 1985).

For measurement of the $\mathrm{G}+\mathrm{C}$ content, the genomic DNA of strain LnR5 $-47^{\mathrm{T}}$ was extracted and purified as described by Moore \& Dowhan (1995) and enzymically degraded into nucleosides. The $\mathrm{G}+\mathrm{C}$ content was then determined as described by Mesbah et al. (1989) using reversed-phase HPLC. Isoprenoid quinones were extracted with chloroform/methanol $(2: 1, \mathrm{v} / \mathrm{v})$, evaporated under a vacuum and re-extracted in $n$-hexane/water $(1: 1, \mathrm{v} / \mathrm{v})$. The crude quinone in $n$-hexane solution was purified using Sep-Pak Vac Cartridges Silica (Waters) and subsequently analysed by HPLC, as described by Hiraishi et al. (1996). Cellular fatty acid profiles were determined using cells grown on R2A agar for 2 days at $30{ }^{\circ} \mathrm{C}$. The cellular fatty acids were saponified, methylated and extracted according to the protocol of the Sherlock Microbial Identification System (MIDI) and identified using capillary GLC (6890; Hewlett Packard) with Sherlock software (version 6.0) and the Sherlock aerobic bacterial database (TSBA60) (Sasser, 1990). DNA-DNA hybridization was performed fluorometrically by the method of Ezaki et al. (1989) using photobiotin-labelled DNA probes and microdilution wells. Hybridization was performed with five replications for

Table 1. Phenotypic characteristics of strain LnR5- $47^{\top}$ and closely related members of the genus Rhodanobacter

Strains: $1, R$. panaciterrae sp. nov. LnR5-47 ${ }^{\mathrm{T}} ; 2, R$. ginsenosidimutans KCTC $22231^{\mathrm{T}}$; 3, R. fulvus KCTC $12098^{\mathrm{T}}$; 4, R. thiooxydans KCTC $12771^{\mathrm{T}}$; 5, R. spathiphylli KACC $12210^{\mathrm{T}}$; 6, R. terrae KACC $11761^{\mathrm{T}}$; 7, R. ginsengisoli KACC $11762^{\mathrm{T}}$. All data were taken from this study unless otherwise stated. All strains are positive for catalase, oxidase, and assimilation of D-glucose and $\mathrm{N}$-acetylglucosamine. All strains are negative for indole production, arginine dihydrolase, urease, and assimilation of L-arabinose, L-rhamnose, malonate, potassium 5ketogluconate and phenylacetic acid. + , Positive; w, weakly positive; - , negative.

\begin{tabular}{|c|c|c|c|c|c|c|c|}
\hline Characteristic & 1 & 2 & 3 & 4 & 5 & 6 & 7 \\
\hline Motility* & - & - & + & - & - & - & + \\
\hline \multicolumn{8}{|l|}{ API 20NE } \\
\hline Nitrate reduction & - & - & - & + & - & - & - \\
\hline Gelatin hydrolysis & - & - & - & + & - & - & + \\
\hline \multicolumn{8}{|l|}{ API ZYM } \\
\hline Esterase (C4) & + & + & - & + & $-\dagger$ & + & + \\
\hline Esterase lipase (C8) & + & + & + & - & + & + & + \\
\hline$\alpha$-Galactosidase & - & + & + & - & - & - & - \\
\hline$\beta$-Galactosidase & - & + & + & + & - & + & - \\
\hline$\beta$-Glucuronidase & - & + & + & - & - & - & - \\
\hline $\begin{array}{l}N \text {-Acetyl- } \beta \text { - } \\
\text { glucosaminidase }\end{array}$ & + & + & + & - & + & - & + \\
\hline \multicolumn{8}{|c|}{ Utilization of (API ID 32GN): } \\
\hline Inositol & - & + & - & - & - & - & - \\
\hline Acetate & - & - & - & - & $+\dagger$ & - & + \\
\hline Melibiose & - & + & + & - & - & - & - \\
\hline L-Fucose & - & - & - & - & - & + & - \\
\hline D-Ribose & + & - & - & + & - & - & - \\
\hline Sucrose & - & + & + & - & - & - & - \\
\hline Glycogen & - & - & - & + & $-\dagger$ & - & - \\
\hline Salicin & - & + & + & - & - & - & - \\
\hline Valerate & - & + & - & + & $+\dagger$ & - & + \\
\hline \multicolumn{8}{|c|}{ Utilization of (API 20NE): } \\
\hline D-Mannose & w & + & + & - & - & + & - \\
\hline $\begin{array}{l}\text { DNA G + C content } \\
(\mathrm{mol} \%)^{*}\end{array}$ & 63.2 & 65.5 & 65.3 & 64.6 & 67.6 & 62.5 & 61 \\
\hline
\end{tabular}

*Data for columns 2-7 were taken from An et al. (2009), Im et al. (2004), Lee et al. (2007), De Clercq et al. (2006) and Weon et al. (2007).

$\dagger$ Discrepancies were found between this study and De Clercq et al. (2006). 
each sample. The highest and lowest values obtained for each sample were excluded and means of the remaining three values were quoted as DNA-DNA relatedness values.

Cells of strain LnR5- $47^{\mathrm{T}}$ were aerobic, Gram-negative, nonmotile, non-spore-forming rods. Colonies grown on R2A agar for 3 days were smooth, circular, convex, transparent and yellowish. The isolate grew well on nutrient agar and TSA and grew slightly on LB agar, but did not grow on MRS agar. The isolate hydrolysed skimmed milk, but not DNA, cellulose, chitin, xylan or starch. $\beta$-Glucosidase activity was detected; this activity was responsible for the conversion of ginsenoside $\mathrm{Rb}_{1}$ to $\mathrm{Rd}$ (data not shown). Other physiological characteristics of strain LnR5 $-47^{\mathrm{T}}$ are summarized in the species description and a comparison of characteristics of strain $\operatorname{LnR} 5-47^{\mathrm{T}}$ with those of closely related type strains is shown in Table 1.

A nearly complete $16 \mathrm{~S}$ rRNA gene sequence (1464 bp, base positions 30-1489 with respect to the Escherichia coli numbering system) was obtained from strain LnR5 $-47^{\mathrm{T}}$. The closest relatives of the isolate were $R$. ginsengisoli GR17- $7^{\mathrm{T}}$ (98.0\% 16S rRNA gene sequence similarity), $R$. terrae GP18$1^{\mathrm{T}}(97.9 \%)$, Dyella ginsengisoli Gsoil $3046^{\mathrm{T}}(97.7 \%)$, R. soli DCY $45^{\mathrm{T}}(97.3 \%)$, Dyella soli $\mathrm{JS} 12-10^{\mathrm{T}}(97.2 \%)$ and Dyella japonica IAM $15069^{\mathrm{T}}(97.1 \%)$. Lower sequence similarity
$(<97.0 \%)$ was found with all other recognized taxa. The close affiliation of strain LnR5 $-47^{\mathrm{T}}$ with the genus Rhodanobacter was also evident in the neighbour-joining tree and supported by the maximum-parsimony analysis (Fig. 1). DNA-DNA relatedness values between strain $\operatorname{LnR} 5-47^{\mathrm{T}}$ and $R$. ginsengisoli GR17-7 $7^{\mathrm{T}}$, R. terrae GP18- ${ }^{\mathrm{T}}$, D. ginsengisoli Gsoil $3046^{\mathrm{T}}$, R. soli DCY $45^{\mathrm{T}}, D$. soli JS12-10 $0^{\mathrm{T}}$ and D. japonica IAM $15069^{\mathrm{T}}$ were $7.1,11.8,25.6,12.7,8.9$ and $25.8 \%$, respectively. According to Wayne et al. (1987) and Stackebrandt \& Goebel (1994), the combined results from the DNA-DNA relatedness and $16 \mathrm{~S}$ rRNA gene sequence studies suggested that strain LnR5- $47^{\mathrm{T}}$ represents a novel species in the genus Rhodanobacter.

The genomic DNA G $+C$ content of strain $\operatorname{LnR} 5-47^{\mathrm{T}}$ was $63.2 \mathrm{~mol} \%$. Q-8 was the major ubiquinone. As shown in Table 2, the major fatty acids of strain $\operatorname{LnR} 5-47^{\mathrm{T}}$ were iso$\mathrm{C}_{16: 0}(20.6 \%)$, iso- $\mathrm{C}_{17: 1} \omega 9 c(20 \%)$ and iso- $\mathrm{C}_{15: 0}(12.5 \%)$. These were consistent with the major fatty acids $(>5 \%)$ of R. spathiphylli KACC $12210^{\mathrm{T}}$, R. terrae GP18-1 ${ }^{\mathrm{T}}$ and $R$. ginsengisoli GR17- $7^{\mathrm{T}}$; however, strain LnR5 $-47^{\mathrm{T}}$ could be distinguished on the basis of qualitative and quantitative differences for these and other fatty acids (Table 2).

In conclusion, phylogenetic analysis based on $16 \mathrm{~S}$ rRNA gene sequences indicated that strain LnR $5-47^{\mathrm{T}}$ belongs to the genus Rhodanobacter, this was supported by chemotaxonomic data,

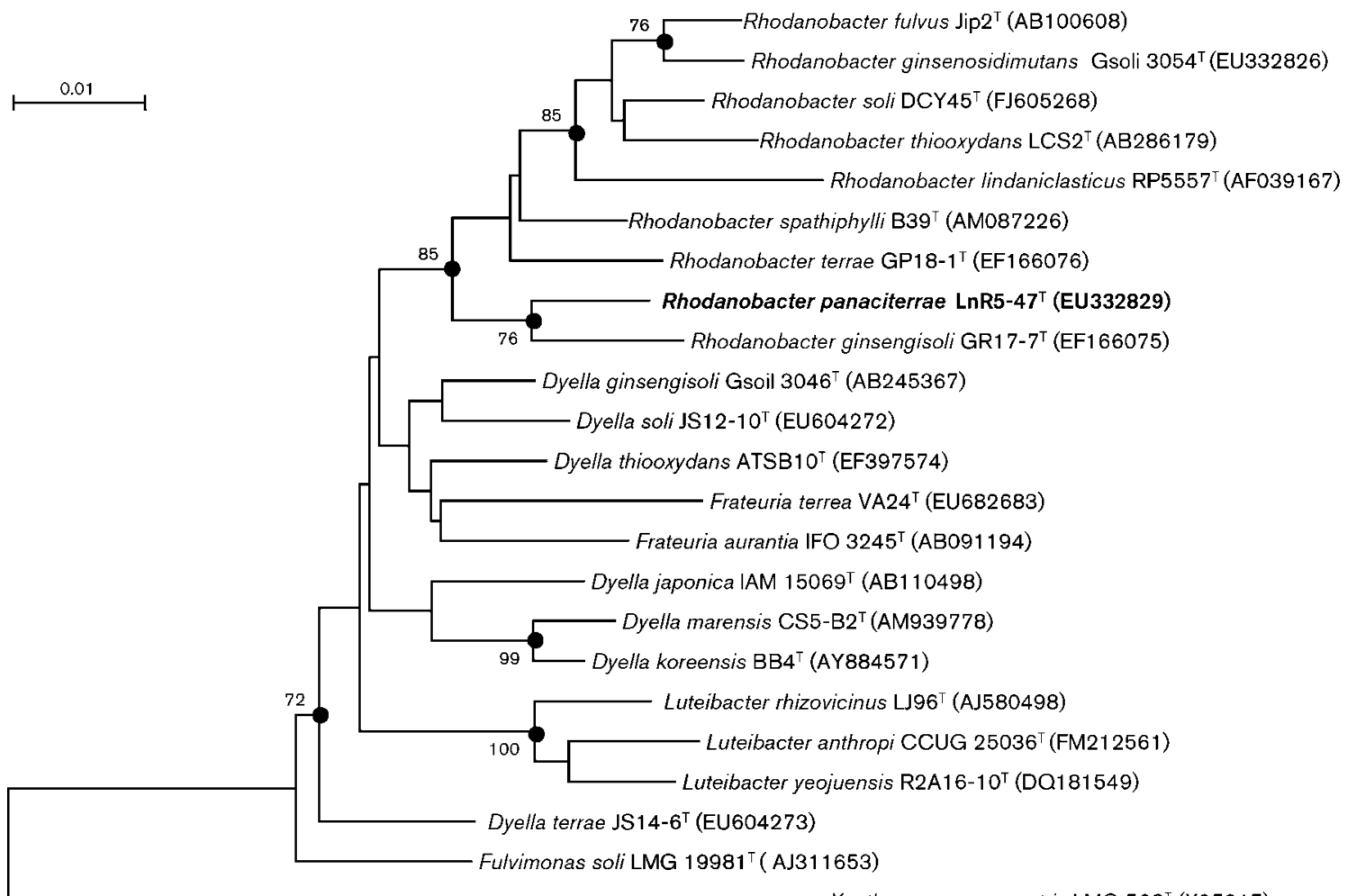

Xanthomonas campestris LMG 568 (X95917)

Fig. 1. Neighbour-joining phylogenetic tree based on $16 \mathrm{~S}$ rRNA gene sequences, showing the relationship of strain $\mathrm{LnR}^{\mathrm{R}}-47^{\top}$ with related taxa. Bootstrap values $(>60 \%)$ based on 1000 replications are shown at branch nodes. Filled circles indicate that nodes were also recovered in the tree generated with the maximum-parsimony algorithm. Bar, 0.01 substitutions per nucleotide. 
Table 2. Cellular fatty acid compositions of strain LnR5-47 and related taxa

Strains: 1 , R. panaciterrae sp. nov. LnR5 $-47^{\mathrm{T}} ; 2$, R. spathiphylli $\mathrm{B} 39^{\mathrm{T}}$; 3, R. terrae GP18-1 $1^{\mathrm{T}} ; 4$, R. ginsengisoli GR $17-7^{\mathrm{T}} ; 5$, Dyella ginsengisoli Gsoil $3046^{\mathrm{T}} ; 6$, Dyella soli JS12-10 ${ }^{\mathrm{T}}$. Data for columns 1, 2, 5 and 6 were taken from this study; data for columns 3 and 4 were from Weon et al. (2007). All strains were analysed under the same conditions. Fatty acids that accounted for $<0.5 \%$ of the total are not shown. Major fatty acids are shown in bold.

\begin{tabular}{|c|c|c|c|c|c|c|}
\hline Fatty acid (\%) & 1 & 2 & 3 & 4 & 5 & 6 \\
\hline \multicolumn{7}{|l|}{ Saturated } \\
\hline $\mathrm{C}_{16: 0}$ & 2.3 & 4.3 & 4.1 & 1.3 & 5.7 & 6.6 \\
\hline $\mathrm{C}_{18: 0}$ & - & - & 1.0 & 1.0 & - & - \\
\hline \multicolumn{7}{|l|}{ Unsaturated } \\
\hline iso- $\mathrm{C}_{16: 1} \mathrm{H}$ & 0.6 & - & - & 0.6 & - & - \\
\hline $\mathrm{C}_{17: 1} \omega 6 c$ & 5.3 & - & 2.7 & 7.2 & - & - \\
\hline \multicolumn{7}{|l|}{ Branched-chain } \\
\hline iso- $\mathrm{C}_{11: 0}$ & 3.5 & - & 3.7 & 8.3 & - & 4.0 \\
\hline iso- $\mathrm{C}_{11: 0} 3-\mathrm{OH}$ & 4.4 & 7.0 & 5.6 & 10.2 & 7.8 & 3.7 \\
\hline iso- $\mathrm{C}_{12: 0} 3-\mathrm{OH}$ & 1.6 & 2.6 & 1.7 & 3.1 & 1.4 & 0.5 \\
\hline iso- $\mathrm{C}_{13: 0} 3-\mathrm{OH}$ & 3.0 & 3.9 & 2.6 & 5.5 & 4.8 & 2.2 \\
\hline iso- $\mathrm{C}_{14: 0}$ & 2.6 & 5.1 & 1.9 & 2.2 & 1.1 & 1.1 \\
\hline iso- $\mathrm{C}_{15: 0}$ & 12.5 & 19.9 & 10.4 & 7.3 & 9.6 & 25 \\
\hline iso- $\mathrm{C}_{16: 0}$ & 20.6 & 20.8 & 19.1 & 14.8 & 16.7 & 14.4 \\
\hline iso- $\mathrm{C}_{17: 0}$ & 5.7 & 7.7 & 8.8 & 4.7 & 13 & 14.5 \\
\hline iso- $\mathrm{C}_{17: 1} \omega 9 c$ & 20 & 14.2 & 19.3 & 16.2 & 17.1 & 10.0 \\
\hline anteiso- $\mathrm{C}_{15: 0}$ & 4.3 & 8.8 & 7.3 & 5.0 & 11.6 & 9.1 \\
\hline anteiso- $\mathrm{C}_{17: 0}$ & 0.5 & 0.5 & 0.7 & - & 2.0 & 2.2 \\
\hline $\mathrm{C}_{17: 0}$ cyclo & - & 0.7 & - & - & 0.8 & - \\
\hline Summed feature $4^{\star}$ & 6.3 & 2.1 & 6.5 & 3.8 & 3.9 & 3.8 \\
\hline
\end{tabular}

${ }^{*}$ Summed features represent two or three fatty acids that cannot be separated by the Microbial Identification System. Summed feature 4 consisted of iso- $\mathrm{C}_{15: 0} 2-\mathrm{OH}$ and/or $\mathrm{C}_{16: 1} \omega 7 c$.

i.e. Q-8 as the predominant ubiquinone, and iso- $\mathrm{C}_{16: 0}$, iso$\mathrm{C}_{17: 1} \omega 9 c$ and iso- $\mathrm{C}_{15: 0}$ as the major fatty acids. However, DNA-DNA relatedness and phenotypic characteristics differentiated strain LnR5- $47^{\mathrm{T}}$ from members of the other established species of Rhodanobacter. Therefore, strain LnR5$47^{\mathrm{T}}$ should be assigned to the genus Rhodanobacter as the type strain of a novel species, for which the name Rhodanobacter panaciterrae sp. nov. is proposed.

\section{Description of Rhodanobacter panaciterrae sp. nov.}

Rhodanobacter panaciterrae (pa.na.ci.ter'ra.e. N.L. n. Panax, -acis scientific name of ginseng; L. n. terra soil; N.L. gen. n. panaciterrae of soil of a ginseng field).

Cells are Gram-negative, aerobic, non-motile rods after growth on R2A agar for 3 days. Colonies on R2A agar after 3 days are smooth, circular, convex, transparent and yellowish. Grows at $10-37{ }^{\circ} \mathrm{C}$, but not at 4 or $42{ }^{\circ} \mathrm{C}$, at pH 4-10 (optimum pH 7.0) and with $0-1 \% \mathrm{NaCl}$ (optimum $0 \% \mathrm{NaCl}$ ). Using the API ID $32 \mathrm{GN}$ system, utilizes D-glucose, maltose, L-proline, $\mathrm{N}$-acetylglucosamine and D-ribose, but not L-arabinose, D-mannitol, caprate, L-histidine, L-alanine, citrate, salicin, 3-hydroxybenzoate, 4-hydroxybenzoate, 3-hydroxybutyrate, itaconate, 2-ketogluconate, lactate, propionate, L-serine, suberate, gluconate, malate, adipate or phenylacetate as sole carbon sources. With the API 20NE system, utilizes maltose but not D-mannitol or citrate. With API ZYM, produces alkaline phosphatase, esterase (C4), esterase lipase (C8), leucine arylamidase, valine arylamidase, acid phosphatase, naphthol-AS-BI-phosphohydrolase and $\beta$-glucosidase (linked with ginsenoside-converting activity), but not $\alpha$ - or $\beta$ galactosidase, $\alpha$-glucosidase, $\beta$-glucuronidase, $\alpha$-mannosidase, $\alpha$-fucosidase, $N$-acetyl- $\beta$-glucosaminidase, lipase (C14) or trypsin. Q-8 is the predominant major ubiquinone and iso$\mathrm{C}_{16: 0}$, iso- $\mathrm{C}_{17: 1} \omega 9 \mathrm{c}$ and iso- $\mathrm{C}_{15: 0}$ are the predominant cellular fatty acids.

The type strain is $\operatorname{LnR} 5-47^{\mathrm{T}}$ (=KACC $12826^{\mathrm{T}}=\mathrm{KCTC}$ $22232^{\mathrm{T}}=\mathrm{LMG} 24460^{\mathrm{T}}$ ), isolated from soil of a ginseng field in Liaoning province, China. The DNA G + C content of the type strain is $63.2 \mathrm{~mol} \%$.

\section{Acknowledgements}

This work was supported by the 21C Frontier Microbial Genomics and Applications Center Program (MG08-0101-2-0) and the Basic Science Research Program through the National Research Foundation of Korea (2010-0006926) which is funded by Ministry of Education, Science \& Technology.

\section{References}

An, D.-S., Lee, H.-G., Lee, S.-T. \& Im, W.-T. (2009). Rhodanobacter ginsenosidimutans sp. nov., isolated from soil of a ginseng field in South Korea. Int J Syst Evol Microbiol 59, 691-694.

Atlas, R. M. (1993). Handbook of Microbiological Media. Edited by L. C. Parks. Boca Raton, FL: CRC Press.

Buck, J. D. (1982). Nonstaining ( $\mathrm{KOH})$ method for determination of gram reactions of marine bacteria. Appl Environ Microbiol 44, 992993.

Bui, T. P. N., Kim, Y.-J., Kim, H. \& Yang, D.-C. (2010). Rhodanobacter soli sp. nov., isolated from soil of a ginseng field. Int J Syst Evol Microbiol 60, 2935-2939.

Chun, J., Lee, J.-H., Jung, Y., Kim, M., Kim, S., Kim, B. K. \& Lim, Y.-W. (2007). EzTaxon: a web-based tool for the identification of prokaryotes based on $16 \mathrm{~S}$ ribosomal RNA gene sequences. Int J Syst Evol Microbiol 57, 2259-2261.

De Clercq, D., Van Trappen, S., Cleenwerck, I., Ceustermans, A., Swings, J., Coosemans, J. \& Ryckeboer, J. (2006). Rhodanobacter spathiphylli sp. nov., a gammaproteobacterium isolated from the roots of Spathiphyllum plants grown in a compost-amended potting mix. Int J Syst Evol Microbiol 56, 1755-1759.

Ezaki, T., Hashimoto, Y. \& Yabuuchi, E. (1989). Fluorometric deoxyribonucleic acid deoxyribonucleic acid hybridization in micro-dilution wells as an alternative to membrane filter hybridization in which radioisotopes are used to determine genetic relatedness among bacterial strains. Int J Syst Bacteriol 39, 224-229.

Felsenstein, J. (1985). Confidence limit on phylogenies: an approach using the bootstrap. Evolution 39, 783-791. 
Fitch, W. M. (1971). Toward defining the course of evolution: minimum change for a specific tree topology. Syst Zool 20, 406-416.

Hall, T. A. (1999). BioEdit: a user-friendly biological sequence alignment editor and analysis program for Windows 95/98/NT. Nucleic Acids Symp Ser 41, 95-98.

Hiraishi, A., Ueda, Y., Ishihara, J. \& Mori, T. (1996). Comparative lipoquinone analysis of influent sewage and activated sludge by highperformance liquid chromatography and photodiode array detection. J Gen Appl Microbiol 42, 457-469.

Im, W.-T., Lee, S.-T. \& Yokota, A. (2004). Rhodanobacter fulvus sp. nov., a $\beta$-galactosidase-producing gammaproteobacterium. J Gen Appl Microbiol 50, 143-147.

Kim, M.-K., Lee, J.-W., Lee, K.-Y. \& Yang, D.-C. (2005). Microbial conversion of major ginsenoside $\mathrm{Rb}_{1}$ to pharmaceutically active minor ginsenoside Rd. J Microbiol 43, 456-462.

Kimura, M. (1983). The Neutral Theory of Molecular Evolution. Cambridge: Cambridge University Press.

Kumar, S., Nei, M., Dudley, J. \& Tamura, K. (2008). MEGA: a biologistcentric software for evolutionary analysis of DNA and protein sequences. Brief Bioinform 9, 299-306.

Lee, C. S., Kim, K. K., Aslam, Z. \& Lee, S.-T. (2007). Rhodanobacter thiooxydans sp. nov., isolated from a biofilm on sulfur particles used in an autotrophic denitrification process. Int J Syst Evol Microbiol 57, 1775-1779.

Liu, Q.-M., Im, W.-T., Lee, M., Yang, D.-C. \& Lee, S.-T. (2006). Dyadobacter ginsengisoli sp. nov., isolated from soil of a ginseng field. Int J Syst Evol Microbiol 56, 1939-1944.

Mergaert, J., Cnockaert, M. C. \& Swings, J. (2002). Fulvimonas soli gen. nov., sp. nov., a $\gamma$-proteobacterium isolated from soil after enrichment on acetylated starch plastic. Int J Syst Evol Microbiol 52, 1285-1289.

Mesbah, M., Premachandran, U. \& Whitman, W. B. (1989). Precise measurement of the $\mathrm{G}+\mathrm{C}$ content of deoxyribonucleic acid by highperformance liquid chromatography. Int J Syst Bacteriol 39, 159-167.

Moore, D. D. \& Dowhan, D. (1995). Preparation and analysis of DNA. In Current Protocols in Molecular Biology, pp. 2-11. Edited by
F. M. Ausubel, R. Brent, R. E. Kingston, D. D. Moore, J. G. Seidman, J. A. Smith \& K. Struhl. New York: Wiley.

Nalin, R., Simonet, P., Vogel, T. M. \& Normand, P. (1999). Rhodanobacter lindaniclasticus gen. nov., sp. nov., a lindane-degrading bacterium. Int J Syst Bacteriol 49, 19-23.

Saitou, N. \& Nei, M. (1987). The neighbor-joining method: a new method for reconstructing phylogenetic trees. Mol Biol Evol 4, 406425.

Sasser, M. (1990). Identification of bacteria by gas chromatography of cellular fatty acids, MIDI Technical Note 101. Newark, DE: MIDI Inc.

Skerman, V. B. D. (1967). A Guide to the Identification of the Genera of Bacteria, 2nd edn. Baltimore: Williams \& Wilkins.

Stackebrandt, E. \& Goebel, B. M. (1994). Taxonomic note: a place for DNA-DNA reassociation and $16 \mathrm{~S}$ rRNA sequence analysis in the present species definition in bacteriology. Int J Syst Bacteriol 44, 846849.

Ten, L. N., Im, W.-T., Kim, M.-K., Kang, M.-S. \& Lee, S.-T. (2004). Development of a plate technique for screening of polysaccharidedegrading microorganisms by using a mixture of insoluble chromogenic substrates. J Microbiol Methods 56, 375-382.

Ten, L. N., Jung, H.-M., Im, W. T., Yoo, S. A. \& Lee, S.-T. (2008). Lysobacter daecheongensis sp. nov., isolated from sediment of stream near the Daechung dam in South Korea. J Microbiol 46, 519-524.

Thompson, J. D., Gibson, T. J., Plewniak, F., Jeanmougin, F. \& Higgins, D. G. (1997). The CLUSTAL_X windows interface: flexible strategies for multiple sequence alignment aided by quality analysis tools. Nucleic Acids Res 25, 4876-4882.

Wayne, L. G., Brenner, D. J., Colwell, R. R., Grimont, P. A. D., Kandler, O., Krichevsky, M. I., Moore, L. H., Moore, W. E. C., Murray, R. G. E. \& other authors (1987). International Committee on Systematic Bacteriology. Report of the ad hoc committee on reconciliation of approaches to bacterial systematics. Int J Syst Bacteriol 37, 463-464.

Weon, H.-Y., Kim, B.-Y., Hong, S.-B., Jeon, Y.-A., Kwon, S.-W., Go, S.-J. \& Koo, B.-S. (2007). Rhodanobacter ginsengisoli sp. nov. and Rhodanobacter terrae sp. nov., isolated from soil cultivated with Korean ginseng. Int J Syst Evol Microbiol 57, 2810-2813. 